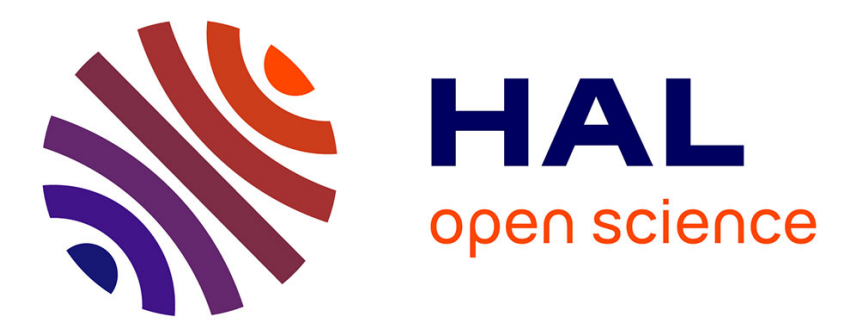

\title{
The stucco technique of the Magistri Comacini: the case study of St. Maria dei Ghirli in Campione d'Italia (Como, Italy)
}

Laura Rampazzi, B. Rizzo, C. Colombo, C. Conti, M. Realini, U. Bartolucci, M. Colombini, A. Spiriti, L. Facchin

\section{To cite this version:}

Laura Rampazzi, B. Rizzo, C. Colombo, C. Conti, M. Realini, et al.. The stucco technique of the Magistri Comacini: the case study of St. Maria dei Ghirli in Campione d'Italia (Como, Italy). Archaeometry, 2012, 54 (5), pp.926-939. 10.1111/j.1475-4754.2011.00651.x . hal-01695511

\section{HAL Id: hal-01695511 https://hal.science/hal-01695511}

Submitted on 29 Jan 2018

HAL is a multi-disciplinary open access archive for the deposit and dissemination of scientific research documents, whether they are published or not. The documents may come from teaching and research institutions in France or abroad, or from public or private research centers.
L'archive ouverte pluridisciplinaire HAL, est destinée au dépôt et à la diffusion de documents scientifiques de niveau recherche, publiés ou non, émanant des établissements d'enseignement et de recherche français ou étrangers, des laboratoires publics ou privés. 


\title{
The stucco technique of the Magistri Comacini: the case study of Santa Maria dei Ghirli in Campione d'Italia (Como, Italy)
}

\section{Laura Rampazzi ${ }^{1 *}$, Biagio Rizzo ${ }^{1}$, Chiara Colombo ${ }^{2}$, Claudia Conti $^{2}$, Marco Realini $^{2}$, Ugo Bartolucci $^{3}$, Maria Perla COLOMbinI ${ }^{3}$, ANDrea SPIrITI ${ }^{4}$, LaURa FaCCHIN ${ }^{5}$}

\footnotetext{
${ }^{1}$ Dipartimento di Scienze Chimiche e Ambientali, Università degli Studi dell’Insubria, via Valleggio 11, 22100 Como, Italy

${ }^{2}$ Istituto per la Conservazione e la Valorizzazione dei Beni Culturali, Unità di Milano 'Gino Bozza', Area della Ricerca Milano 3 Bicocca, via Cozzi 53, 20125 Milano, Italy.

${ }^{3}$ Dipartimento di Chimica e Chimica Industriale, Università di Pisa, Via Risorgimento 35, 56126 Pisa, Italy

${ }^{4}$ Dipartimento di Informatica e Comunicazione, Università degli Studi dell'Insubria, Via Mazzini 5, 21100 Varese, Italy.

${ }^{5}$ Scuola di Dottorato in Studi Umanistici, Università degli Studi di Verona, Facoltà di Lettere e Filosofia, Dipartimento di Arte, Storia e Società, via S. Francesco 22, 37129 Verona, Italy.
}

*Corresponding author

Laura Rampazzi, email address: laura.rampazzi@uninsubria.it; phone number: +390312386475; fax number: +390312386449

\begin{abstract}
This article is aimed to define the artistic technique performed by the outstanding artist Isidoro Bianchi for the Baroque stucco decorations in the church of Santa Maria dei Ghirli (Campione d'Italia, Italy). Samples of stucco were examined by means of optical microscopy, scanning electron microscopy with microprobe, X-ray powder diffraction, Fourier transform infrared spectroscopy, gas chromatography-mass spectrometry and laser ablation mass spectrometry equipped with plasma source spectrometry. On the basis of the results obtained art historians made new hypotheses on the biography of the artist and on the historical location of his birthplace.
\end{abstract}

Keywords: $\quad$ stuccoes, Baroque, artistic technique, Magistri Comacini, microscopic analyses, spectrometric analyses, laser ablation 


\section{Introduction}

The study presented in this article investigates the artistic technique used for the Baroque stucco decorations in Santa Maria dei Ghirli, located in Campione d'Italia (Como), a sovereign Italian territory completely surrounded by Swiss territory and facing the lake of Lugano.

The research is part of a wider program of analytical campaigns within the project L'arte dello Stucco nel Parco dei Magistri Comacini - Valorizzazione, conservazione e promozione (The art of stucco in the Magistri Comacini Park Enhancement, conservation and promotion, referred to as 'Stucco Project' in the text), funded by the European Community Cross-border co-operation III A Program in order to promote the cultural heritage in the borderline area between Italy and Switzerland (Various Authors, 2006). In particular, the project managed by Insubria University of Como (Italy) and SUPSI University of Lugano (Switzerland) was focused on the stucco works from five churches and some civil buildings spread between the lakes of Como and Lugano, with the aim of comparing the decoration techniques.

The authors of these decorations were the so-called 'Magistri Comacini', known also as 'Artists of the Lakes': painters, sculptors, architects coming from the aforementioned lakes, and working from the Middles Ages to nowadays. The artists used to work all over Italy and Europe for most of the year and return home during wintertime. On these occasions they usually enriched the local heritage, e.g. by making stucco decorations, which are still unknown outside the region and need to be investigated and compared to similar case studies all around Europe.

One of the most outstanding sites decorated by the Magistri Comacini is the church of Santa Maria dei Ghirli, whose plaster decorations date back to the great period of Baroque stucco artworks. In that period, i.e. $17^{\text {th }}$ and $18^{\text {th }}$ centuries, stucco had a starring role in architectural decorating, both polychromatic and enriched by gilded finishing, and sometimes made with casts in order to improve the modelling. The mixture of lime or gypsum binder, sometimes combined with sand and rock fragments, gripped the overhanging finishings to iron or wood frames, and the organic additives ensured workability and plasticity (Davey 1971). Many finishing layers could be applied for aesthetic or conservative purposes and a complex stratigraphy is often observed on the external surface. The Scagliola technique, very similar to stucco technology, was perfected in Emilia Romagna, Tuscany and Lombardy (Intelvi Valley) in the same period. Altarpieces, sculptures, and panels were produced mixing gypsum, organic additives and pigments in order to imitate precious natural stones such as marbles.

New light on the stucco technique used in Santa Maria dei Ghirli was shed by the exploitation of an analytical protocol set up in a previous work (Rampazzi 2008) and by the discussion of the results with art historians, in order to be sure that they make sense if compared to the cultural and artistic scenario of that time and to the artist's fingerprint. This paper describes an interdisciplinary and complementary team approach, which resulted in enhancing our knowledge of the decoration from the point of view of its conservation state, composition, technique of preparation, history, iconography, philology, chronology, and relationships to contemporary artists.

In particular, the analytical protocol (Rampazzi 2008) made use of various analytical techniques, complementary in decrypting the layer arrangement and the composition of the stucco decorations: Fourier transform infrared spectroscopy (FTIR), X-ray diffraction (XRD), scanning electron microscope equipped with energy dispersive spectroscopy (SEM-EDS), gas chromatography-mass spectrometry (GC-MS) and laser ablation mass spectrometry equipped with plasma source (LA-ICP-MS). The aforementioned techniques are some of the most popularly used methods. FTIR identifies the inorganic and organic compounds and XRD determines the crystalline phases of the 
minerals (Montana 2002; Cavallo 2005; Tulliani 2005; Cardell-Fernandez 2006; Galván-Ruiz 2009; Mazzocchin 2010; Sansonetti 2010); SEM-EDS investigates the morphology and maps the element along the stratigraphy (Montana 2002; Galván-Ruiz 2009; Sansonetti 2010); GC-MS allows the determination of the organic content (Wouters 2000) and LAICP-MS traces the element content on the surface (Giussani 2009). In particular, the coupling of LA-ICP-MS and SEM proved effective in distinguishing layers very thin and similar from the compositional point of view, thanks to the high sensitivity for trace elements analysis of the former and to the high resolution of the latter (Rampazzi 2008).

\subsection{Historical and artistic background}

The cycle of the Santa Maria dei Ghirli church is an interesting case of stucco decoration in early Baroque style, still influenced by mannerist accents. The building is placed in Campione d'Italia, a small Italian enclave in Switzerland that actively contributed toward the artistic development of many European cities since medieval times through the work of the Campione Masters, part of the wider group of the 'Artists of the Lakes' (A. Spiriti in Various Authors, 2006, pages 27-32). The main nucleus of Santa Maria dei Ghirli church was probably built in the 7-8 $8^{\text {th }}$ century, and between 777 and 874 it became the property of the monastery of Sant' Ambrogio in Milan and under its jurisdiction. The growing devotion to the Virgin Mary (the church is dedicated to the Annunciation) favoured enlargements and remakings of the building over the centuries, particularly in the second half of the $14^{\text {th }}$ and early $15^{\text {th }}$ century (Colombo 1988).

In the first decades of the $17^{\text {th }}$ century important architectural and decorative modifications gave to the church the present aspect. The project was planned by Isidoro Bianchi (Campione d'Italia, 1581-1662), an artist who used to work as painter, sculptor and engineer in Prague, Lombardy and especially as court painter for the Savoy dynasty in Turin where he was the leader of a team which involved firstly Antonio and Pietro Castelli and later his sons, Pompeo and Francesco (Grabach 1997; Dell'Omo 2003). According to the dates painted and carved on the walls, the work started at least in 1610-12 and lasted until 1634 (De Angelis 1988). Isidoro Bianchi planned the new lantern and dome connected with the third span of the single nave and covered by a barrel vault, partially remodelled the presbytery area, and coordinated the artist's team that dealt with the interior decoration, i.e. frescoes and stuccoes.

The Ghirli cycle had been only considered in a wider range of studies on Lombardy religious building and on Isidoro Bianchi himself (Colombo 1988; De Angelis 1988), but it had never been the object of a specific essay until the research carried out within the 'Stucco Project' (various authors 2006). The archival investigation was focused especially on notarial deeds (such as contracts, wills and proxies) kept in the State Archive of Milan, in order to better reconstruct the decoration cycle's chronology and the artists that modelled it. The research moved to the text written by Roberto Rusca (1566-1629/after), Ambrosian monk and Vicar of Campione (1620-1623), most probably the patron of the whole enterprise. His chronicle, published in two different editions (Bergamo 1625 and Piacenza 1629), recorded the execution of most of the stucco decoration during the years 1620-21-22 (Rusca 1625).

The other two stucco campaigns were probably carried out by still unknown artists. The former took place in 1686, as suggested by the date found during the last conservation work in winter-spring 2010, involving the frames in the presbytery side walls. The latter dated back to the $3^{\text {rd }}-4^{\text {th }}$ decade of the $18^{\text {th }}$ century, as confirmed by archive documents, contemporary to the completion of the façade on Isidoro Bianchi's project. The campaign concerned the presbytery pilaster strips which were decorated with the brand new Rococo sensibility spread throughout Europe by the 'Artists of the Lakes' during the first decades of the $18^{\text {th }}$ century (Spiriti 2010). 


\section{Experimental}

Some meaningful decorations (Figure 1) were sampled according to art historians' suggestions (Table 1). In particular, the historical and artistic background influenced the samples' selection on two principles. The former suggested the localization in those areas where Bianchi's work was documented, i.e. the presbytery, the vault, the high altar and at the highest part of the nave vault. The second principle suggested sampling different typologies of stucco patterns, i.e. the decorative parts (e.g. the scrolls, normally executed by the master's team with use of moulds) and the altar angels' statues with an in the round decoration, certainly made by the lead artist Isidoro Bianchi.
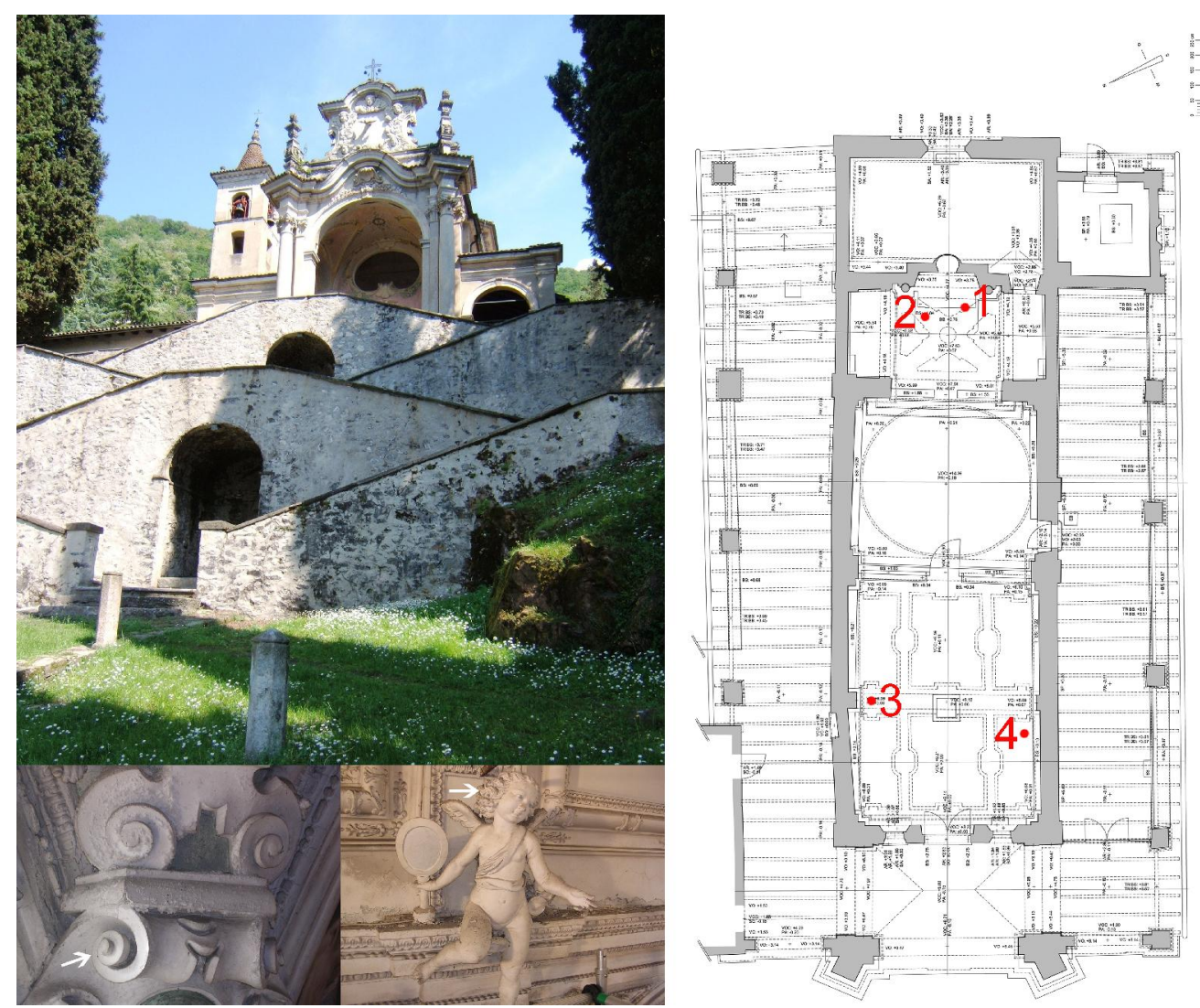

Figure 1 Clockwise from upper left: Picture of the church of Santa Maria dei Ghirli, church plan with sample location, photographs showing the stucco decorations from which sample 3 and sample 2 were taken.

The micro samples were collected by means of a scalpel according to the indication of UNI-Normal $3 / 80$ [Raccomandazione Normal 3/80: Materiali lapidei: campionamento, CNR-ICR, Roma (1980)]. Small fragments of each sample were analysed as polished cross sections. Preliminary morphological observation were carried out by Leitz Wild M420 stereomicroscope on polished micro-fragments and thin cross sections (30 $\mu \mathrm{m}$ thick) of the samples were observed respectively in reflected light using a Leitz Ortholux microscope with Ultropack illuminator and in polarized light by a Nikon Eclipse E400Pol microscope. All microscopes were equipped with a digital-image capture system. Porosimetric analyses were carried out on fragments of the middle portion after mechanical separation with a lancet under the stereomicroscope. Cubic samples of about $1 \mathrm{~cm}$ edge were analysed with Thermoquest mercury porosimeter: configuration Pascal 240 was used to determine pores with radius among 7.5 e $3.7 \times 10^{-3} \mu \mathrm{m}$ and configuration Pascal 140 to determine pores with radius among 50 and $1 \mu \mathrm{m}$. Scanning electron microscopy (SEM) investigations of 
fragments and polished cross sections were carried out by a JEOL 5910LV microscope equipped with an X-ray spectrometer (IXRF Systems/EDS 2000). Images were acquired in backscattered mode and EDS qualitative spectra were collected from 0 to $20 \mathrm{keV}$ for $100 \mathrm{sec}$, using a beam current of 1-3 $\times 10^{-7} \mathrm{~A}$. The XRD analyses were carried out on the middle portions, after mechanical separation from the rest of the samples. Fine powders of the samples were analysed with a Bruker AXS D8 ADVANCE diffractometer with the following conditions: generator settings $40 \mathrm{kV}$ and $40 \mathrm{~mA}$; fenditure divergence slit 1.0; RS $0.2 \mathrm{~mm} ; \mathrm{R}=217.5 \mathrm{~mm}$; radiation $\mathrm{Cu}-\mathrm{K} \alpha ; \lambda=1.5418 \AA$; pyrolytic graphite monochromator with diffracted ray; geometry $\theta$ : $\theta$; soller slits $2.3^{\circ}$; continuous scan $1{ }^{\circ} / \mathrm{min} ; \Delta 2 \theta=0.02^{\circ}$; scan range 5$55^{\circ}$; deep quarter sampler $200 \mu \mathrm{m}$. The samples were analysed as KBr pellets by an FTIR spectrophotometer (Nicolet Nexus), in transmission mode (400 to $4000 \mathrm{~cm}^{-1}, 4 \mathrm{~cm}^{-1}$ resolution). If possible, the main portions of the stucco stratigraphy were analysed separately. In order to avoid contamination among the finishing and the body mortar, the samples were carefully collected under a stereomicroscope by means of a needle-sampler. The sample was subjected to a GC-MS analytical procedure reported in detail in the literature (Andreotti 2006). It consists of an ammonia extraction which allows the separation of the proteinaceous material from lipids, resins, bituminous material and waxes, an acidic hydrolysis of the proteinaceous fraction in order to release the amino-acids, and an analysis by GC-MS after derivatisation with MTBSTFA ( $\mathrm{N},-$ methyl-N-(t-buthyldimethylsylil)trifluoracetamide). The residue of the ammonia extraction is subjected to saponification, followed by acidification, derivatisation with BSTFA (N,O-bistrimethylsyliltrifluoracetamide) and GC-MS analysis. When interference by high concentrations of sulphates on amino-acid determination occurred, a modified approach based on the addition of $\mathrm{BaCl}_{2}$ solution (the precipitation of sulphates occurs when the $\mathrm{BaCl}_{2}$ concentration is $0.02 \mathrm{M}$ in the hydrolysate) to the acid hydrolysate, followed by filtration, was used. LA-ICP-MS analyses were performed by ICP-MS (Thermo X-serie due, $10 \mathrm{~ms}$ dwell time, 1 channel of mass, sweep number 100, power $1300 \mathrm{~W}$ ) equipped with a laser ablation system (UP266, New Wave Research). The ablation step was optimised as follows: laser output $1.56 \mathrm{~mJ}$ surface power (55\%), repetition rate $20 \mathrm{~Hz}$, spot size $20 \mu \mathrm{m}$, scan speed $2 \mu \mathrm{m} / \mathrm{s}$ in continuous mode. A pre-ablation step was performed to clean the sample surfaces using a weak energy laser spot.

\begin{tabular}{|c|l|l|}
\hline Sample & Description & Historical notes-Attribution \\
\hline 1 & Fragment of stucco: Altar; angel caryatid head & Isidoro Bianchi and teamworkers \\
\hline 2 & Fragment of stucco: Presbitery, pendentive; volute & Isidoro Bianchi and teamworkers \\
\hline 3 & $\begin{array}{l}\text { Fragment of stucco: Nave, left side; angel statue holding } \\
\text { a mirror }\end{array}$ & Isidoro Bianchi and teamworkers \\
\hline 4 & $\begin{array}{l}\text { Fragment of stucco: Nave, right side, pendentive; angel } \\
\text { statue holding a cartouche }\end{array}$ & Isidoro Bianchi and teamworkers \\
\hline
\end{tabular}

Table 1 Sampling and description of the microfragments of stucco.

\section{Results and discussion}

Information about the stratigraphy was obtained from observations carried out on thin and polished cross sections by optical and scanning electron microscopy, while EDS, XRD, FTIR, GC-MS and LA-ICP-MS techniques clarified the composition, in terms of major, minor and trace elements. 
The stucco was generally composed of at least three layers (UNI10924, 2001):

- $\quad$ the inner one, i.e. the bulk, composed by a whitish mortar;

- $\quad$ the middle one, made by a more plastic white mortar showing a thickness around $8 \mathrm{~mm}$;

- $\quad$ the outer part, made mainly by a binder fraction, which was characterised by a white-greyish colour with a thickness around 20-40 microns.

The main components-of the bulk was lime binder. Clots were observed within the binder fraction, due to the coagulation of particles during the lime slaking process. The phenomenon was probably caused by the presence inside the slaked lime of a fraction of lime already carbonated before use (Bugini 1980). The aggregate showed a low sorting (with size ranging from few microns to $1-2 \mathrm{~mm}$ ) and a high packing, and was mainly constituted by fragments of silicate metamorphic rocks, many crystals of silicate minerals and calcite, and by iron oxides. From the mineralogical point of view no significant differences were detected in the samples, as probably coming from the same raw materials sources.

As far as the middle portion of the stuccoes is concerned, the open total porosity values ranged from $25 \%$ to $28 \%$, with a prevalent porosimetric distribution in the 0.25 and $0.05 \mu \mathrm{m}$ pores class. The average thickness was about $8 \mathrm{~mm}$. The binder was composed by magnesic lime, as shown by microscopic observations. Calcite and magnesite $\left(\mathrm{MgCO}_{3}\right)$ signals were determined in FTIR and XRD spectra as well. Samples 1, 3 and 4 also contained hydromagnesite $\left[\mathrm{Mg}_{5}\left(\mathrm{CO}_{3}\right)_{4}(\mathrm{OH})_{2} 4\left(\mathrm{H}_{2} \mathrm{O}\right)\right]$, as suggested by the peculiar FTIR absorbance peaks at 3649,3512 and $3447 \mathrm{~cm}^{-1}$, and 1428 , $1423 \mathrm{~cm}^{-1}$, due to the presence of two kinds of carbonate ions in the molecule (Bruni 1998) (Figure 2a). XRD analyses confirmed the presence of hydromagnesite in sample 3 and sample 4 . The presence of hydromagnesite is due to the use of dolomite rocks as binder and/or as aggregate (Atzeni 1996). Moreover, according to the literature its crystallization among sand grains usually induces better mechanical strengths to mortars (Caceres 1997; Dheilly 1999). Gypsum was determined by thin section observations, XRD and FTIR analyses only in sample 2 and, in traces, in sample 1. Clots of lime and gypsum were observed in samples 2 and 3, as clearly shown by Figure 3a. 

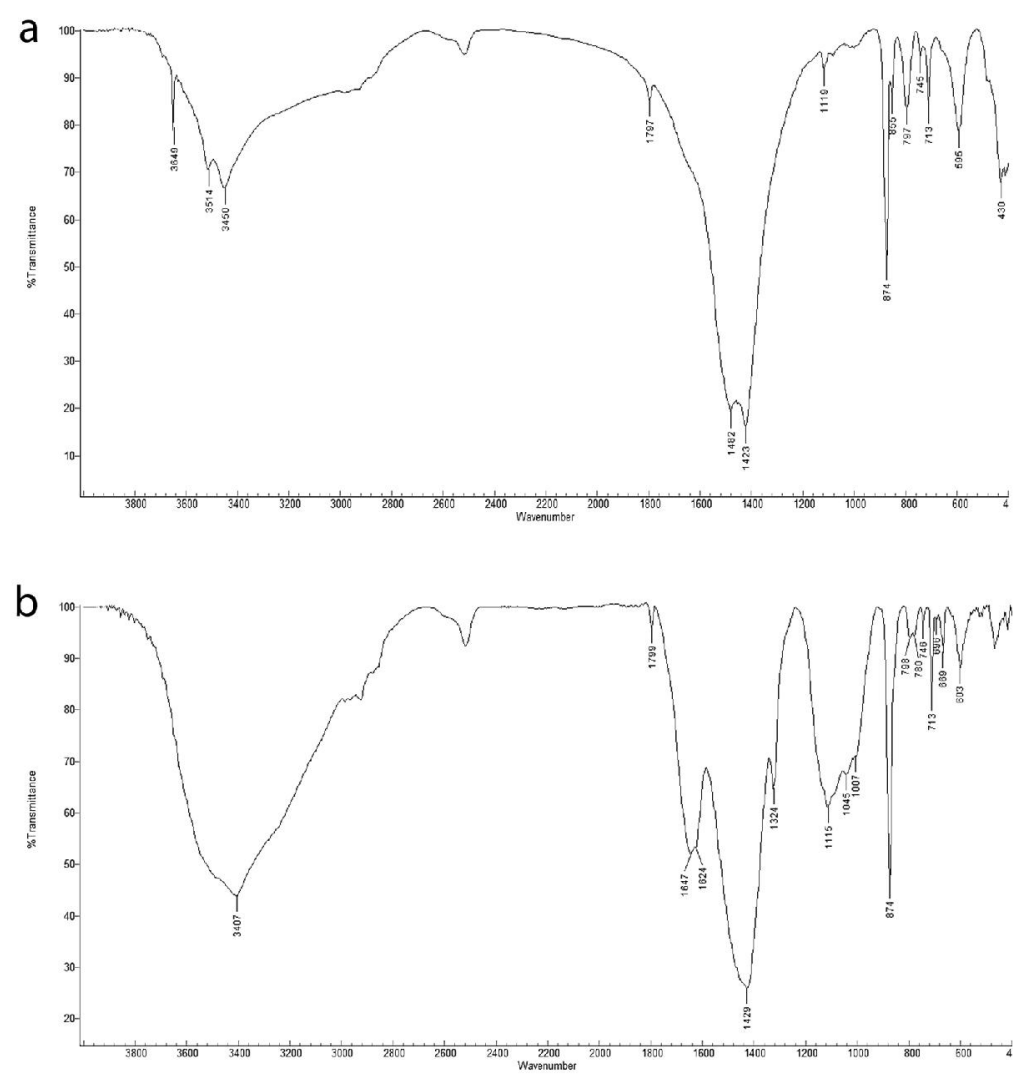

Figure 2 FTIR transmittance spectra of the stucco layer of sample 4 (a), showing the co-presence of calcite $\left(874,713 \mathrm{~cm}^{-1}\right)$, magnesite $\left(744 \mathrm{~cm}^{-1}\right)$ and hydromagnesite $\left(3649,3512,3447,1428\right.$ and $\left.1423 \mathrm{~cm}^{-1}\right)$, and of the finishing layer of sample 1 (b), showing the presence of weddellite (1647 and $1324 \mathrm{~cm}^{-1}$ ).

As regards the aggregate of the middle portion, it showed a high sorting (with average size of $500 \mu \mathrm{m}$ ) and a low packing, and was mainly constituted of fragments of carbonaceous rocks (both sedimentary and metamorphic) and of low amounts of metamorphic rocks, except for sample 4, that contained mainly carbonatic fragments. XRD investigation ascertained the presence in sample 1 and 2 of phyllosilicates, that may be ascribed to the metamorphic rocks fraction. EDX maps of element distribution of calcium, magnesium, silicon and sulphur showed how the presence of $\mathrm{Si}$ in the aggregate was very low, while the gypsum was present both in the binder and in the clots (Figure 3b).

Of significant interest from the investigation of the finishing layers is that the outer part is very simple and only in two samples composed by one or two layers (Figure 4). It is surprising, since according to the technology commonly adopted by Magistri Comacini the stucco decorations were completed with a number of finishing layers (Cavallo 2005; Rampazzi 2008). The external surfaces of stucco portions of samples 3 and 4 appeared covered only by deposit particles, composed by silicates, iron and calcium oxalate in the former and phosphates in the latter. LA-ICP-MS profile confirmed the enrichment of iron on the external surface of sample 3. Sample 1 presents only one finishing layer, made of magnesic lime, gypsum and calcium oxalate. 


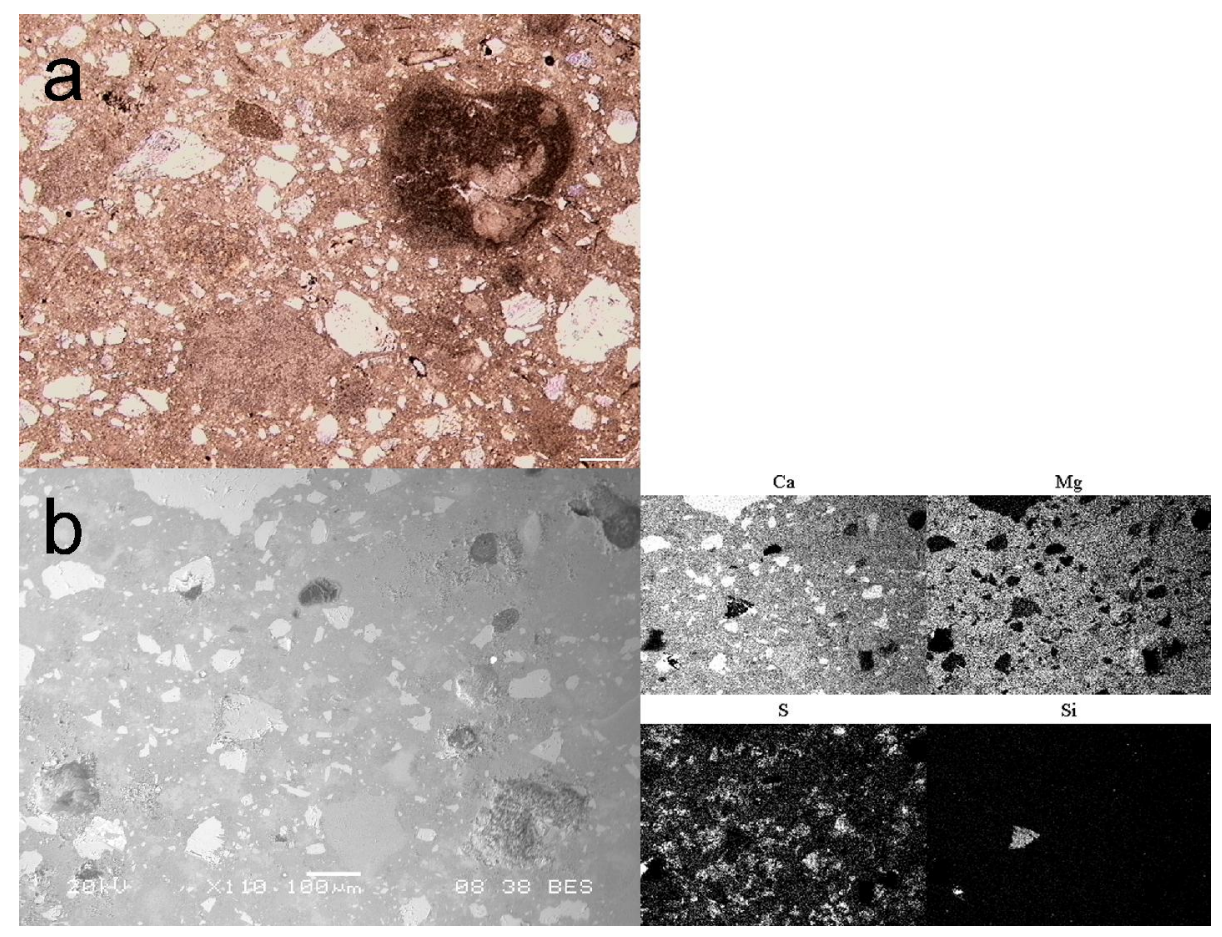

Figure 3. Thin cross section (a) of sample 2 (bar $200 \mu \mathrm{m}$ ), showing the presence of lime and gypsum clots (Nicol $45^{\circ}$ ), and polished cross section (b) of sample 2 analysed by SEM-EDS, backscattered image (bar $100 \mu \mathrm{m}$ ) and EDX distribution maps of $\mathrm{Ca}, \mathrm{Mg}, \mathrm{Si}$ and $\mathrm{S}$ of the same area (clockwise from upper left).

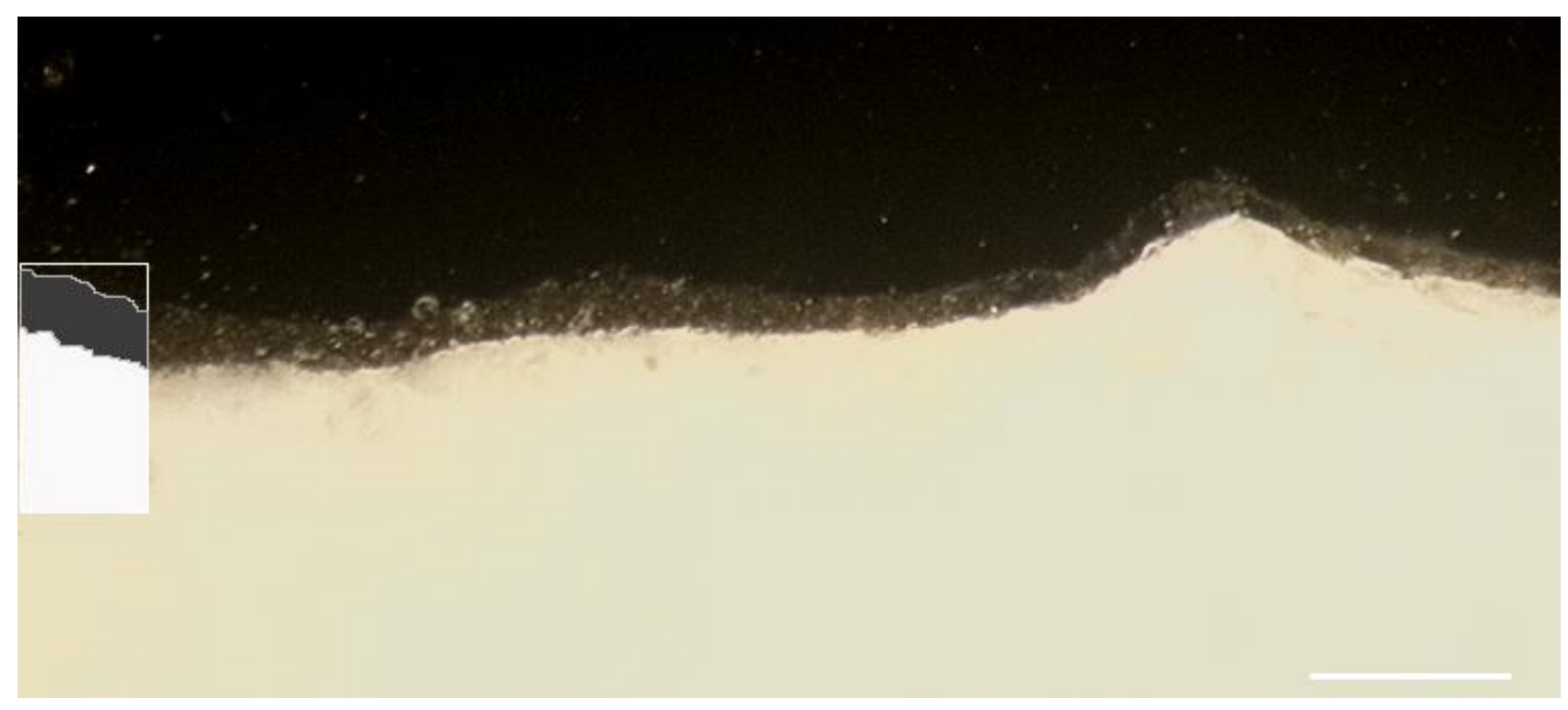

Figure 4. Polished cross section and stratigraphic scheme of sample 1 (bar $100 \mu \mathrm{m})$ showing the presence of just one finishing layer.

The composition of sample 2 is peculiar and differs from the other ones. It presents two finishing layers (Figure 5). The external one is composed only by magnesic lime, while the internal one is constituted by lime and gypsum clots. SEMEDX analyses pointed out the presence of barium, sulphur and zinc, suggesting the presence of barium white $\left(\mathrm{BaSO}_{4}\right)$ and zinc white $(\mathrm{ZnO})$. Both the pigments date to the $19^{\text {th }}$ century (Feller 1986; Kuhn 1986), thus indicating an ante quem period for the application of a finishing layer, probably on occasion of a conservation work. A restoration of the whole building, including stucco decorations, was actually documented between 1910 and 1911 by the parish priest's report during the periodical pastoral visitation (Archivio 1911). Past surface treatments usually consisted of 
maintenance application of opaque or glossy coatings to make uniform and protect the decayed surface, or of making the appearance of the ancient decorations and brand new ones uniform (Zanardi 1989).

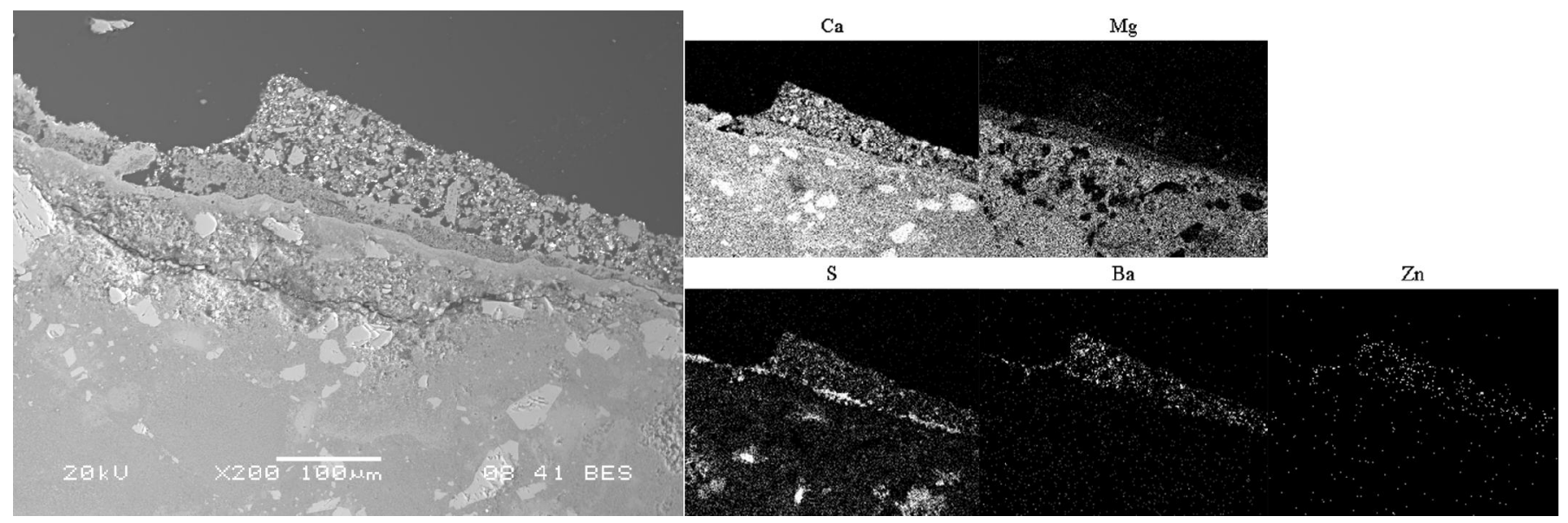

Figure 5. Polished cross section of sample 2 analysed by SEM-EDS. Backscattered image of polished cross section (bar $100 \mu \mathrm{m})$ and EDX distribution maps of $\mathrm{Ca}, \mathrm{Mg}, \mathrm{Zn}, \mathrm{Ba}$ and $\mathrm{S}$ of the same area (clockwise from upper left).

As far as the characterisation of the organic components of the finishing and stucco layers is concerned, Table 2 reports the amino acid percentage contents (w/w\%) obtained by quantitative GC-MS analyses. The results showed that:

- only samples 1 ( $0.4 \mathrm{ppm}$ both for stucco layer and finishing layer) and 4 (0.4 ppm for stucco layer, $1.6 \mathrm{ppm}$ for external surface) contained amounts of a proteinaceous material above the quantification limit (LOQ $=0.05 \mathrm{ppm}$ );

- samples 2 and 3 had amino acid values close to the detection limits ( $\mathrm{LOD}=0.01 \mathrm{ppm})$;

- the absence of hydroxyproline, which rules out the presence of animal glue;

- a quite high amount of glycine (15-20\%), which can be attributed to the effect of biological agents such as fungi or bacteria: the metabolism product of many bacteria is indeed glycine (Colombini 2010).

\begin{tabular}{|l|l|l|l|l|l|l|l|l|l|l|l|l|}
\hline Sample & ala & gly & val & leu & ile & ser & pro & phe & asp & glu & hyp & ppm \\
\hline 1 finishing layer & 16.5 & 19.8 & 10.6 & 14.1 & 7.7 & 4.9 & 5.3 & 5.5 & 6.7 & 8.9 & 0.0 & 0.4 \\
\hline 1 stucco layer & 12.8 & 16.4 & 13.6 & 16.6 & 5.7 & 3.3 & 4.4 & 2.2 & 12.9 & 12.1 & 0.0 & 0.4 \\
\hline 2 finishing layer & 25.2 & 24.3 & 10.1 & 13.3 & 16.5 & 4.3 & 2.2 & 2.7 & 0.8 & 0.6 & 0.0 & $<$ LOD \\
\hline 2 stucco layer & 23.6 & 24.3 & 11.7 & 13.0 & 15.8 & 5.3 & 0.8 & 2.3 & 2.6 & 0.6 & 0.0 & $<$ LOD \\
\hline 3 finishing layer & 22.0 & 26.0 & 12.0 & 15.2 & 15.3 & 3.6 & 1.2 & 2.0 & 2.2 & 0.5 & 0.0 & $<$ LOD \\
\hline 3 stucco layer & 21.7 & 26.3 & 14.2 & 13.0 & 18.3 & 1.6 & 1.2 & 1.0 & 1.2 & 1.0 & 0.0 & $<$ LOD \\
\hline 4 external surface & 10.2 & 17.4 & 12.6 & 17.3 & 7.7 & 4.8 & 4.8 & 3.5 & 12.3 & 9.3 & 0.0 & 1.6 \\
\hline 4 stucco layer & 14.5 & 14.6 & 14.5 & 16.8 & 5.2 & 3.2 & 6.8 & 1.6 & 15.3 & 7.6 & 0.0 & 0.4 \\
\hline
\end{tabular}

Table 2: Amino acid percentage contents of the samples and the content (ppm) of proteinaceous material. [ala (alanine), gly (glycine), val (valine), leu (leucine), ile (isoleucine), ser (serine), pro (prolinae), phe (phenilalanine), asp (aspartic acid), glu (glutammic acid), hyp (hydroxyproline), LOD=limit of detection].

Since the principal component analysis (PCA) of amino acid contents is a very powerful technique for pattern recognition (Colombini 2004), it was applied to the data of Table 2 for samples 1 and 4 which presented a proteinaceous content higher than the LOQ. Figure 6 reports the score plot and the loading plot of PCA applied to the amino acid percentage contents: the first two principal components account for $74.1 \%$ of the total variance. The samples form a cluster close to the composition of egg. Basically, the difference in the $\mathrm{PC} 1$ values are mainly due to the high percentage of glycine which causes a shift towards the animal glue cluster. Moreover, the effect of the ageing acts on the values of PC2 which are slightly higher in respect to the reference values. Notwithstanding these, the results suggest the presence 
of egg both in stucco and finishing layers.

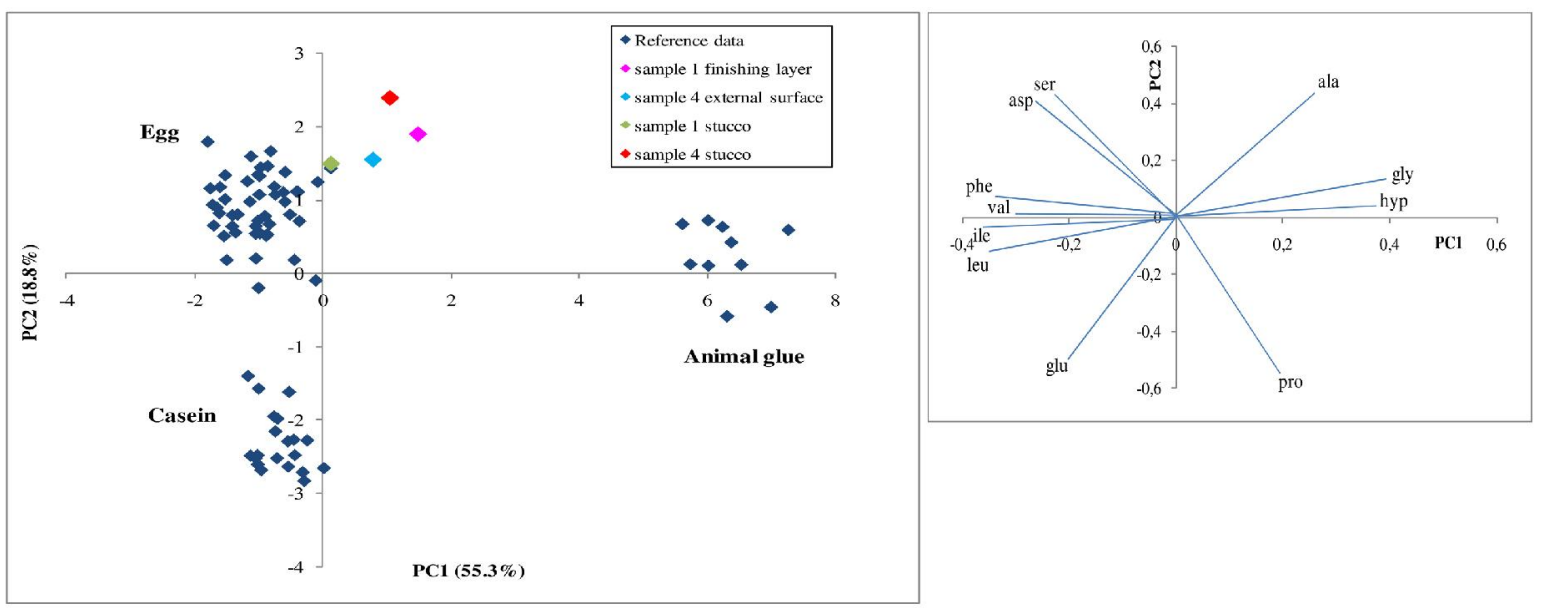

Figure 6 PCA score plot (left) and loading plot (right) of amino acid percentage contents of samples from St. Maria dei Ghirli.

Of special interest was the presence of calcium oxalate dehydrate $\left(\mathrm{CaC}_{2} \mathrm{O}_{4} 2 \mathrm{H}_{2} \mathrm{O}\right.$, weddellite) in the finishing layers of sample 1 (Figure 2b), and on the external surfaces of samples 3 and 4 . The compound was identified by the typical FTIR absorbance bands at around 1640 and $1326 \mathrm{~cm}^{-1}$, due respectively to the O-C-O antisymmetric and symmetric stretching vibrations. The chemical origin of calcium oxalate from the mineralisation of organic compounds has been assessed (Cariati 2000; Rampazzi 2004; Luveras 2008; Campos-Suñol 2008 and 2009), although the formation of the films as by product of a surface microflora should be also taken into account. Since SEM morphological investigations did not indicate the presence of either past or present bio-colonisation, calcium oxalate could have formed by the oxidative degradation of the organic additives often added in the past to stuccoes in order to enhance their workability. A close look at the stucco decorations made it possible to notice signs of shaping the surfaces with pads, especially in case of angels' cheeks or other curved areas. This was very common in the practice of the artists of the Lombard Lakes. Similar signs were found in Diego Francesco Carloni's work in Kollegienkirche in Salzburg (1706-1707) attributed to the Beltramelli family and the Giorgio Ferretti stucco cycle in Madonna del Popolo sanctuary in Cherasco (Piedmont, Italy 1703-1709) (Facchin 2010).

Otherwise, organic compounds could have been used as polishing surface treatments. The hypothesis seemed to be confirmed by the presence of egg in samples 1 and 4 as well as by the occurrence of apatite in sample 4 , as suggested by the FTIR peaks at 1092 and $1034 \mathrm{~cm}^{-1}$ and by SEM-EDX analyses (Figure 7). Apatite may in fact come by the mineralization of organic compounds treatments containing phospho-compounds (Rampazzi 2004) and as a consequence could have been originated in the same way as calcium oxalate. 


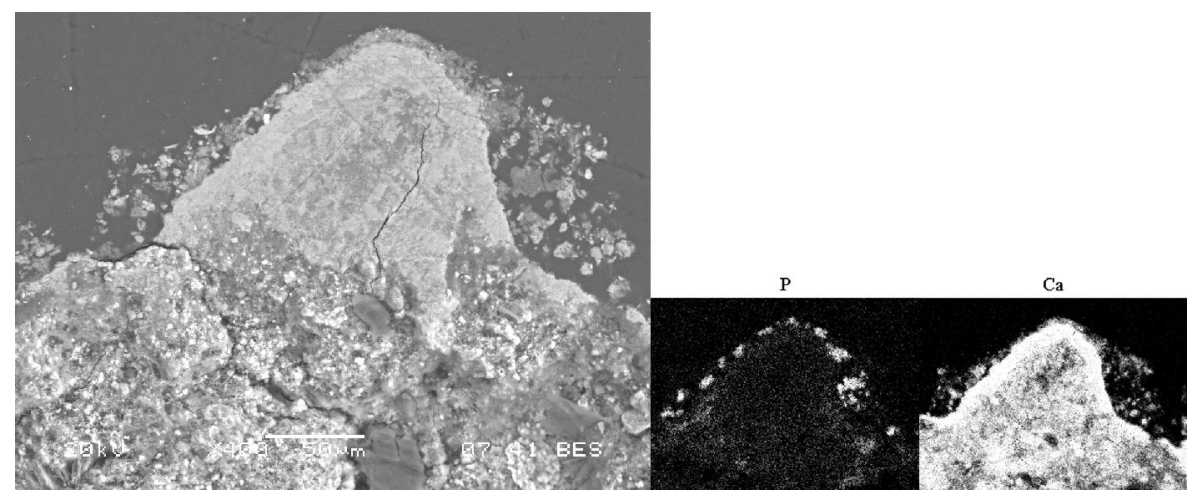

Figure 7 Polished cross section of sample 4 analysed by SEM-EDS. Backscattered image of polished cross section (left, bar 50 $\mu$ m), EDX distribution maps of $\mathrm{P}$ and $\mathrm{Ca}$ of the same area (right).

In samples 1 and 4 a lead enrichment in the external portion of the finishing layers was identified by LA-ICP-MS analyses (Figure 8). The high sensitivity of the technique is effective for the analysis of trace element profiles not detectable by SEM-EDX investigations, thus completing the element maps along the stratigraphy. The polished cross sections of the samples were analyzed by SEM-EDS, in order to determine the major and minor elements and to define into details the stratigraphy, in particular the number and thickness of the layers. In the next step, this map guided the laser along the stratigraphy, linking the distribution of elements to the single layers. The presence of lead suggested the use of lead moulds which "contaminated" the surfaces during the set, leaving trace concentrations of lead. The use of moulds for repeated decorative elements is described in art treatises.

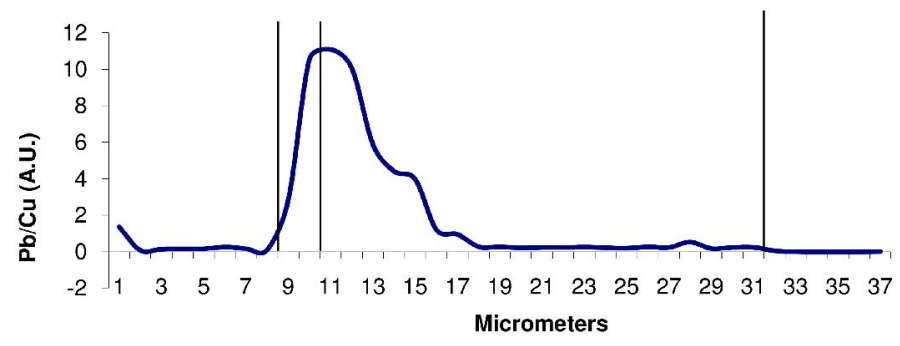

Figure 8 LA-ICP-MS analysis of sample 1: lead content variation along the stratigraphy.

\section{Conclusions}

The analytical campaign on the stucco artworks of S. Maria dei Ghirli church allowed the construction of an hypothesis on Isidoro Bianchi's decoration technique. The comparison between the compositional data of artworks and their semantic and historical context proved effective for the clarification of chronological, and stylistic, problems and the knowledge of materials. In particular, the stratigraphy was able to shed a light on some chronological problems. According to literary sources, Isidoro Bianchi's team decoration campaign took place in a single phase from 1620 to $1623 / 25$ on the occasion of the 1625 Jubilee year. This is confirmed by the similar composition and stratigraphy of the stucco decorations released in the altar and in the nave (samples 1, 3 and 4). The sample coming from the presbytery vault (sample 2) gave different results for the presence of gypsum in the binder fraction, probably in order to emphasize an illusionistic use of stucco, typical of Baroque style, as imitation of more precious marbles, thanks to the brightness effects of the surface. 
The presence of various collaborators in Santa Maria dei Ghirli site, according to 'Artists of the Lakes' tradition, was probably due to a specific request for a quick execution of the interior stucco decoration and to the hurry in accomplishing the campaign before the Jubilee event. This hypothesis is corroborated by the analytical results. The presence of organic compounds enhanced in fact the workability. Moreover, the stratigraphy investigation showed the rather coarse quality of stucco elements and way of shaping, since the finishing layers were surprisingly absent or plain. The effort to give a bright appearance to the decoration surface suggests that Isidoro Bianchi and his team probably intended to conclude the campaign in a more suitable moment, with much time available, or under more propitious economic conditions. The lead enrichment in the finishing layers of one sample suggested the use of moulds, once again to make the decorating quicker, especially for decorative parts such as cartouches, vegetable elements (i.g. leaves), scrolls.

Notwithstanding the uniformity of chemical and mineralogical composition in 3 of the 4 samples analyzed, some differences in patterns and shaping, together with the documentary evidences, allowed us to distinguish four different artists, probably including Isidoro Bianchi. The identity of Isidoro Bianchi's collaborators is still unknown, except for his sons. It is possible to suggest the name of Antonio and Pietro Castelli from Melide, Isidoro's partners when he worked in Turin. The determination of peculiar pigments dating back to the $19^{\text {th }}$ century is probably connected to the restoration works between 1910 and 1911. Although not described in the archive documents, the stucco restoration could have been carried out in order to refresh the aged surfaces only where necessary, possibly with a thin layer of plaster as a few traces were found. The most seriously damaged area of the stucco decorations was certainly that of the presbytery vault, from which sample 2 was taken, because of a documented deep crack.

\section{Acknowledgments}

The authors gratefully acknowledge the financial support provided by the EU Interreg IIIA Program and D. Di Tommaso and Don E. Mosca for the church plan.

\section{REFERENCES}

Andreotti, A., Bonaduce, I., Colombini, M.P., Gautier, G., Modugno, F., Ribechini, E., 2006, Combined GC/MS analytical procedure for the characterization of glycerolipid, waxy, resinous, and proteinaceous materials in a unique paint microsample, Analytical Chemistry, 78, 4490-4500.

Archivio Storico Diocesano di Milano, 1911, Visite Pastorali, Pievi Milanesi, arcivescovo Andrea C. Ferrari, vol. III.

Atzeni, C., Massidda, L., Sunna, U., 1996, Magnesian Limes. Experimental contribution to interpreting historical data, Science and Technology for Cultural Heritage, 5, 29-36

Bruni, S., Cariati, F., Fermo, P., Pozzi, A., Toniolo, L., 1998, Characterization of ancient magnesian mortars coming from northern Italy, Thermochimica Acta, 321, 161-165.

Bugini, R., Toniolo, L., 1980, The presence of white lumps in ancient mortars, Arkos, 12, 4-8.

Caceres, P.G., Attiogbe, E.K., 1997, Thermal decomposition of dolomite and the extraction of its constituents, Minerals Engineering, 10, 1165-1176.

Campos-Suñol, M. J., Domínguez-Vidal, A., Ayora-Cañad,a M. J., De la Torre-López, M. J., 2008, Renaissance patinas in Úbeda (Spain): mineralogic, petrographic and spectroscopic study, Analytical and Bioanalytical Chemistry, 391, 1039-1048.

Campos-Sunol, M. J., De la Torre-Lopez, M. J., Ayora-Canada, M. J., Dominguez-Vidal, A., 2009, Analytical study of polychromy on exterior sculpted stone, Journal of Raman Spectroscopy, 40, 2104-2110.

Cardell-Fernández, C., Navarrete-Aguilera, C., 2006, Pigment and plasterwork analyses of Nasrid polychromed lacework stucco in the Alhambra (Granada, Spain), Studies in Conservation, 51, 161-176.

Cariati, F., Rampazzi, L., Toniolo, L., Pozzi, A., 2000, Calcium oxalate films on stone surfaces: experimental assessment of the chemical formation, Studies in Conservation, 45, 180-188.

Cavallo, G., Derighetti, L., Napoli, S., 2005, The emigration of prealpine lake masters: a study of a 17th-century 
mantelpiece attributed to the Carlone family of Rovio (Ticino, Switzerland), Archaeometry, 47, 425.

Colombini, M.P., Modugno, F., 2004, Characterisation of proteinaceous binders in artistic paintings by chromatographic techniques, Journal of Separation Science, 27, 147-160.

Colombini, M.P., Andreotti, A., Bonaduce, I., Modugno, F., Ribechini, E., 2010, Analytical strategies for characterizing organic paint media using gas chromatography/mass spectrometry, Accounts of Chemical Research, 43, 715-727.

Colombo, S., 1988, Storia del monumento, in 'Il Santuario di Santa Maria dei Ghirli in Campione d'Italia' (eds. G. A. Dell'Acqua Cinisello Balsamo), Amilcare Pizzi Editore, 51-55.

Davey, N., 1971, A history of building materials, Phoenix House London.

De Angelis M., 1988, Affreschi e stucchi del XVII secolo, in GIl Santuario di Santa Maria dei Ghirli in Campione d'Italia (eds. G. A. Dell'Acqua Cinisello Balsamo), Amilcare Pizzi Editore, Cinisello Balsamo, 145-146.

Dell'Omo, M., 2003, Da Praga a Torino: gli inizi di Isidoro Bianchi. Nuove ipotesi e qualche novità dai documenti, in 'Isidoro Bianchi 1581-1662 di Campione', (eds. D. Pescarmona), Silvana Editoriale, Cinisello Balsamo, 24-25.

Dheilly, R.M., Bouguerra, A., Beaudoin, B., Tudo, J., Queneudec, M., 1999, Hydromagnesite development in magnesian lime mortars, Materials Science and Engineering, A268, 127-131

Facchin L., Stucchi rocailles nel Piemonte sabaudo all'inizio del XVIII secolo, in Proceedings of workshop 'Il Rococò: nascita di un linguaggio artistico', (eds. A. Spiriti, B. Bolandrini), Brignano Gera d'Adda, Treviolo (Italy), 2010, 40-50.

Feller, R. L., 1986, Barium Sulphate - Natural and Synthetic in Artists' pigments, Vol.1, (eds. R.L. Feller), Oxford University Press.

Giussani, B., Monticelli, D., Rampazzi, L., 2009, Role of Laser Ablation-Inductively Coupled Plasma-Mass Spectrometry in Cultural Heritage research: a review, Analytica Chimica Acta, 635, 6-21.

Galván-Ruiz, M., Velázquez-Castillo, R., Pérez-Lara, M. A., Arjona, J. L., Baños, L., Rodríguez-García, M. E., 2009, Chemical and physical characterizationof stuccos from a Mexican colonial building: el Museo del Calendario of Queretaro, Archaeometry, 51, 701-714.

Grabach, T., 1997, in S.A.U.R. Allgemeines Künstler-Lexicon, Munchen-Leipzig, G. B. S.AU.R, 17, 189-190.

Kuhn, H., 1986, Zinc White in Artists' pigments, Vol.1, (eds. R.L. Feller), Oxford University Press.

Lluveras, A., Boularand, S., Roquè, J., Cotte, M., Gir Aldez, P., Vendrell-Saz, M., 2008, Weathering of gilding decorations investigated by SR: development and distribution of calcium oxalates in the case of Sant Benet de Bages (Barcelona, Spain), Applied Physics A, 90, 23-33.

Mazzocchin, G. A., Vianello, A., Minghelli, S., Rudello, D., 2010, Analysis of roman wall paintings from the thermae o f 'Iulia Concordia', Archaeometry, 52, 644-655.

Montana, G., Ronca, F., 2002, The 'recipe' of the stucco sculptures of Giacomo Serpotta, Journal of Cultural Heritage, 3, 133 .

Rampazzi, L., Andreotti, A., Bonaduce, I., Colombini, M. P., Colombo, C., Toniolo, L., 2004, Analytical investigation of calcium oxalate films on marble monuments, Talanta, 63, 967-977.

Rampazzi, L., Rizzo, B., Colombo, C., Conti, C., Realini, M., Bartolucci, U., Colombini, M. P., Spiriti, A., Facchin, L., 2008, The stuccoes of St. Lorenzo in Laino (Como, Italy): the materials and the techniques employed by the "Magistri Comacini”, Analytica Chimica Acta, 630, 91-100.

Rusca, R., 1629, La descrittione del borgo di Campione et altri luoghi circonvicini et particolarmente di Lugano, Bergamo, appresso Valerio Ventura, 1625, page 50; R. Rusca, Il Rusco, ouero breue descrittione del contado \& vescouado comasco per linea dritta, et trauersale libro quarto, nel quale particolarmente si descriuono la citta di Como, Locarno, Lugano, Varesio, Seprio,Canturio, Bellagio, Lecco, Campione, Elimonte, Acqua fredda, \& Mendrisio ..., Piacenza, apresso Giacomo Ardizone, 76.

Sansonetti, A., Striova, J., Biondelli, D., Castellucci, E. M., 2010, Colored grounds of gilt stucco surfaces as analyzed by a combined microscopic, spectroscopic and elemental analytical approach, Analytical and Bioanalytical Chemistry, 397, 2667-2676.

Spiriti, A., 2010, La nascita del Rococò problemi e certezze, 'Il Rococò: nascita di un linguaggio artistico', (eds. A. Spiriti, B. Bolandrini), Treviolo (Italy), 7-15.

Tulliani, J. M., Bertolini Cestari, C., 2005, Study of the degradtion causes affecting stucco sculptures from the Valentino Castle in Turin, Materials and Structures, 38, 425.

UNI10924:2001 Cultural Heritage - Mortars for building and decorative elements - Classification and terminology. UNI - Milan.

Various Authors, 2006, Proceedings of the Final Conference on the Interreg IIIA Project 'L'arte dello stucco (The art of stucco)', New Press, Como.

Wouters, J., Van Bos, M., Lamens, K., 2000, Baroque stucco marble decorations. II. Composition and degradation of the organic materials in historical samples and implications for their conservation, Studies in Conservation, 45, 169.

Zanardi, B., 1989, La superbia della bianchezza del marmo in Proceedings of the 1st International Symposium The oxalate films. Origin and significance in the conservation of works of art, ed. Centro "Gino Bozza", Milano, 39-52. 